\title{
Tectonic Implications of a Remagnetization Event in the Newark Basin
}

\author{
WILLIAMK. WITTE AND DENNIS V. KENT \\ Lamont-Doherty Geological Observatory, Columbia University, Palisades, New York
}

\begin{abstract}
The Newark basin red beds contain a secondary magnetization (the B component) acquired during the Middle Jurassic after the $5^{\circ}-20^{\circ}$ basin-wide northwesterly dip was imparted to the strata of the basin and after most, if not all, of the limb rotation in the Jacksonwald syncline. The B component magnetization was most likely related to the same hydrothemal event which evidently remagnetized many of the igneous intrusions in the basin and reset their K/Ar systems at $175 \mathrm{Ma}$. The remagnetization of the red beds occurred over a few million years and was approximately coincident with the transition from continental rifting to seafloor spreading in the adjacent North Atlantic. The $B$ component magnetization direction yields a paleomagnetic pole at $74^{\circ} \mathrm{N}, 96^{\circ} \mathrm{E}\left(K=63, A_{95}=2.6^{\circ}, N=50\right.$ sites $)$ after structural correction for $1 / 3$ of the Jacksonwald folding and none of the regional tilt. This pole supports recent evidence for a highlatitude model of Jurassic apparent polar wander for North America.
\end{abstract}

\section{INTRODUCTION}

The Newark basin of Pennsylvania and New Jersey contains a thick lacustrine and fluvial clastic section whose deposition spans at least $25 \mathrm{~m} . \mathrm{y}$. of the Late Triassic (middle Carnian) to earliest Jurassic (Hettangian). The natural remanent magnetism (NRM) of these red beds consists of a characteristic magnetization (the $\mathrm{C}$ component) and an ubiquitous secondary magnetization (the $\mathrm{B}$ component). The high unblocking temperature $\left(>640^{\circ} \mathrm{C}\right) \mathrm{C}$ component has been isolated in studies of the lower Newark strata (the Stockton, Lockatong, and lowest Passaic formations [Witte and Kent, 1989]), the middle Newark strata with a positive fold test (the Passaic Formation [Witte et al., 1991]), and the upper Newark strata (the Newark extrusive zone [Witte and Kent, 1990]). The lower, middle, and upper Newark studies yield similar pole positions after tilt correction $\left(54^{\circ} \mathrm{N}, 102^{\circ} \mathrm{E} ; 56^{\circ} \mathrm{N}, 95^{\circ} \mathrm{E}\right.$; and $55^{\circ} \mathrm{N}, 95^{\circ} \mathrm{E}$, respectively) which suggest a very slow rate of North American apparent polar wander (APW) during the Late Triassic and earliest Jurassic.

The pervasive B component is invariably of normal polarity (northward with $\sim+40^{\circ}$ inclination) and is effectively isolated between $300^{\circ} \mathrm{C}$ and $600^{\circ} \mathrm{C}$ [Witte and Kent, 1989, 1990]. The $B$ component direction was well defined in those studies, although it was not clear whether the remagnetization occurred before or after stratal tilting. Likewise, as was noted by Witte and Kent [1989], it remains unclear whether the Newark trend igneous $\mathrm{N} 2$ pole should be tilt corrected. The choice of a reference frame for these poles has important consequences for the Middle Jurassic North American APW path.

The purpose of the present study is to test explicitly the timing of the acquisition of the $B$ component relative to structural tilting and to determine the appropriate reference frame for the $\mathbf{B}$ component paleomagnetic pole. Accordingly, we have sampled the red beds in a more complex structural setting than the homoclinal regions where we have previously sampled. By comparing the B component magnetizations isolated at various stratigraphic levels throughout the geographic extent of the basin we have also endeavored to explore the spatial variation of the remagnetization.

Copyright 1991 by the American Geophysical Union.

Paper number 91JB01866.

0148-0227/91/91JB-01866\$05.00

\section{PREVIOUS WORK}

In addition to the clastic rocks, the Newark basin also includes closely related suites of diabase intrusive rocks and tholeiitic basalt flows. Paleomagnetic results from the igneous rocks associated with the Newark and other eastern North American rift basins have played an important role in the interpretation of the Jurassic North American APW path. For example, the compilation by Smith and Noltimier [1979] yielded two statistically distinct reference poles, $\mathrm{N} 1\left(63^{\circ} \mathrm{N}, 83^{\circ} \mathrm{E}\right)$ and $\mathrm{N} 2$ $\left(65^{\circ} \mathrm{N}, 103^{\circ} \mathrm{E}\right)$, which were thought to correspond with two igneous events [Sutter and Smith, 1979] dated at $179 \mathrm{Ma}$ and $195 \mathrm{Ma}$, respectively (R/Ar ages corrected for new decay constants). While the $\mathrm{N} 1$ and $\mathrm{N} 2$ poles have been key paleomagnetic reference poles in recent models of Jurassic North American APW [Gordon et al., 1984; May and Butler, 1986], field and radiometric studies now indicate that igneous activity in at least the Newark and Gettysburg basins (which were the source of many of the N1 and N2 data) was confined to a short time interval in the earliest Jurassic at $200 \mathrm{Ma}$ [Kodama, 1983; Ratcliffe, 1988; Sutter, 1988; Dunning and Hodych, 1990].

The N1 pole consists of results from the basalts of the Newark and Hartford basin extrusive zones and from selected diabase intrusions in the Hartford basin. Biostratigraphic evidence indicates that the extrusive episode in the Newark and Hartford basins began very early in the Jurassic [Cornet, 1977; Cornet and Olsen, 1985], and further analysis has indicated the extrusive episode probably lasted less than $1 \mathrm{~m} . \mathrm{y}$. [Olsen and Fedosh, 1988]. Although the basalts and the intercalated red beds of the Newark extrusive zone all yield normal polarity magnetizations, the mean magnetization direction after alternating field (AF) demagnetization of the basalts is significantly steeper than the mean high unblocking temperature magnetization isolated in the red beds of the extrusive zone (upper Newark) [McIntosh et al., 1985; Witte and Kent, 1990]. We interpreted this disparity as resulting from residual contamination of a basalt primary magnetization by Middle Jurassic or younger overprints [Witte and Kent, 1990].

The N2 pole consists of results from intrusions in Maryland, Pennsylvania, New Jersey, Connecticut, and Nova Scotia that were once thought to have been emplaced at about $179 \mathrm{Ma}$. However, recent $\mathrm{U} / \mathrm{Pb}$ zircon dates from the Palisades and Gettysburg sills, two of the major intrusive sheets from which 
data contributing to the $\mathrm{N} 2$ pole were obtained, show that the sills crystallized at $201 \pm 1$ Ma [Dunning and Hodych, 1990], similar to the age of the extrusives. These crystallization ages are consistent with observations that the Palisades sill actually fed some of the basalt flows in the Newark basin [Kodama, 1983; Ratcliffe, 1988] and imply that the intrusive and extrusive rocks were crystallized in a single igneous episode. Yet, the $\mathrm{N} 2$ pole $\left(65^{\circ} \mathrm{N}, 103^{\circ} \mathrm{E}\right)$ differs significantly from the $\mathrm{N} 1$ pole $\left(63^{\circ} \mathrm{N}, 83^{\circ} \mathrm{E}\right.$, or the depositionally coeval Hettangian upper Newark pole, $55^{\circ} \mathrm{N}, 95^{\circ} \mathrm{E}$ ) and falls on a much younger part of Gordon et al.'s [1984] or May and Butler's [1986] North American APW paths than the demonstrated crystallization age of the igneous rocks would indicate. We have interpreted this disparity as evidence that the $\mathrm{N} 2$ pole does not represent a primary thermal remanent magnetization, but rather a secondary magnetization most likely acquired during a hydrothermal episode that Sutter [1988] suggested reset the $\mathrm{K} / \mathrm{Ar}$ geochronometers in the diabase intrusions of the Newark, Gettysburg, and Culpepper basins at about $175 \mathrm{Ma}$ [Witte and Kent, 1989].

More than half of the site mean virtual geomagnetic poles (VGPs) included in the N2 compilation were obtained from diabase intrusions of the Newark and Gettysburg basins and were corrected for tilt [Beck, 1972]. The B component magnetization isolated from the lower Newark red beds yielded a mean pole position similar to the pole from this subset of N2 when both are compared in the same (either geographic or tilt corrected) reference frame [Witte and Kent, 1989]. The uniform normal polarities and similar directions of the $B$ and N2 magnetizations suggest that both were acquired as secondary magnetizations at about the same time, most likely during the $175 \mathrm{Ma}$ hydrothermal event [Sutter, 1988]. The N2 magnetizations have been incorporated into the literature with the assumption that they were acquired before tilting; however, this assumption was not demonstrated by field evidence such as a fold test. The timing of the acquisition of the B component secondary magnetization with respect to the tilting of the basin strata has similarly not been tested. If the remagnetizations occurred before tilting, then the $B$ component and N2 pole positions would support a mid-latitude APW path in the Jurassic similar to that suggested by Gordon et al. [1984] or May and Butler [1986]. If the remagnetization was acquired after tilting, however, then the B component and N2 poles would support a high-latitude Jurassic APW path, as suggested by Irving and Irving [1982] and Van Fossen and Kent [1990].

\section{Sampling}

We have previously reported $B$ component site mean directions from 22 sites in the middle Carnian/early Norian Stockton, Lockatong, and Passaic formations in the central Newark basin [Witte and Kent, 1989] and from four sites in the Hettangian sedimentary rocks of the extrusive zone in the northern Newark basin (Witte and Kent, 1990) (Figure 1). These 26 sites sampled relatively homoclinal strata, dipping $5^{\circ}-20^{\circ}$ to the northwest, which did not offer sufficient bedding attitude variation for a fold test.

The present paper includes new results from 27 sites sampling middle and late Norian strata of the predominantly lacustrine red beds of the Passaic Formation. Most (18) of the sites are from the Jacksonwald syncline and associated folds in the southern part of the basin where the bedding is dipping up to $70^{\circ}$ to the north and south, and nine sites are from the northern and central parts of the basin in regions of northwest dipping homoclinal strata (Figure 1). Sampling site locations are listed by Witte et al. [1991], where the characteristic (C component) magnetization of these 27 sites is also described. At least five cores were drilled with a portable drill at each site except one (TGF) where nine oriented hand samples were taken. Field orientations were obtained with a magnetic compass and verified in heavily urbanized zones with a solar compass or geographic sightings.

\section{Paleomagnetic Results}

The NRM of the $10 \mathrm{~cm}^{3}$ samples was measured on an ScT cryogenic magnetometer and ranged in intensity from $\sim 0.2$ to $\sim 60 \mathrm{~mA} / \mathrm{m}$. AF demagnetization to $100 \mathrm{~m}$ T was ineffective in resolving components of magnetization in the Newark red beds owing to high coercivities, but progressive thermal demagnetization revealed two ancient components of magnetization (Figure 2). Typically between $300^{\circ} \mathrm{C}$ and at least $600^{\circ} \mathrm{C}$, linear demagnetization trajectories indicated the unblocking of a component of magnetization directed uniformly northward and moderately down (the B component). Above about $640^{\circ} \mathrm{C}$, demagnetization trajectories that converged to the origin indicated unblocking of the characteristic magnetization, the $\mathbf{C}$ component, which occurs in two nearly antipodal populations directed northward and southward with shallow inclinations [Witte et al., 1991].

Principal component analysis (PCA) [Kirschvink, 1980] was used to estimate the direction of linear demagnetization trajectories for each specimen. Only one site, TJK, failed to produce reliable estimates of the $\mathrm{B}$ (or $\mathrm{C}$ ) component and the samples displayed very low unblocking temperatures and anomalously high NRM intensities and susceptibilities. This site was taken from altered sediments within $50 \mathrm{~m}$ of a diabase intrusion which most likely altered the magnetic mineralogy of the red beds. The other 26 sites yielded at least three estimates of the B component direction from independently oriented samples which were averaged by the method of Fisher [1953] to give site means (Table 1). The $\mathbf{B}$ component magnetization site mean directions of these 26 sites yielded an overall mean direction of $357.4^{\circ} / 46.9^{\circ}\left(k=33, \alpha_{95}=5.0^{\circ}\right)$ in geographic coordinates and $353.9^{\circ} / 29.8^{\circ}\left(k=17, \alpha_{95}=7.2^{\circ}\right)$ after a simple bedding tilt correction (rotating the bedding to horizontal about the present strike). The factor of 2 decrease in the precision parameter $k$ already suggests that the $\mathrm{B}$ component was acquired during or after folding and tilting.

\section{Fold Test}

Of the 26 middle Newark sites with reliable estimates of $B$ component directions, 15 were taken on the limbs of the Jacksonwald syncline. A PCA fit to the poles to bedding observed at the 15 sites in the Jacksonwald syncline yields a fold axis plunging $+13^{\circ}$ toward an azimuth of $289^{\circ}$ (Figure 3). Samples from two sites on the north limb of a small unnamed anticline immediately to the north of the Jacksonwald yielded reliable paleomagnetic results, but these sites (TJL and TJM) were excluded from further analysis because of the lack of sufficient structural control on plunge.

The small, but measurable, plunge of the Jacksonwald syncline allows us to consider structurally correcting the $B$ component magnetization directions by a two-step method, which entails a combination of a rotation about the fold axis 

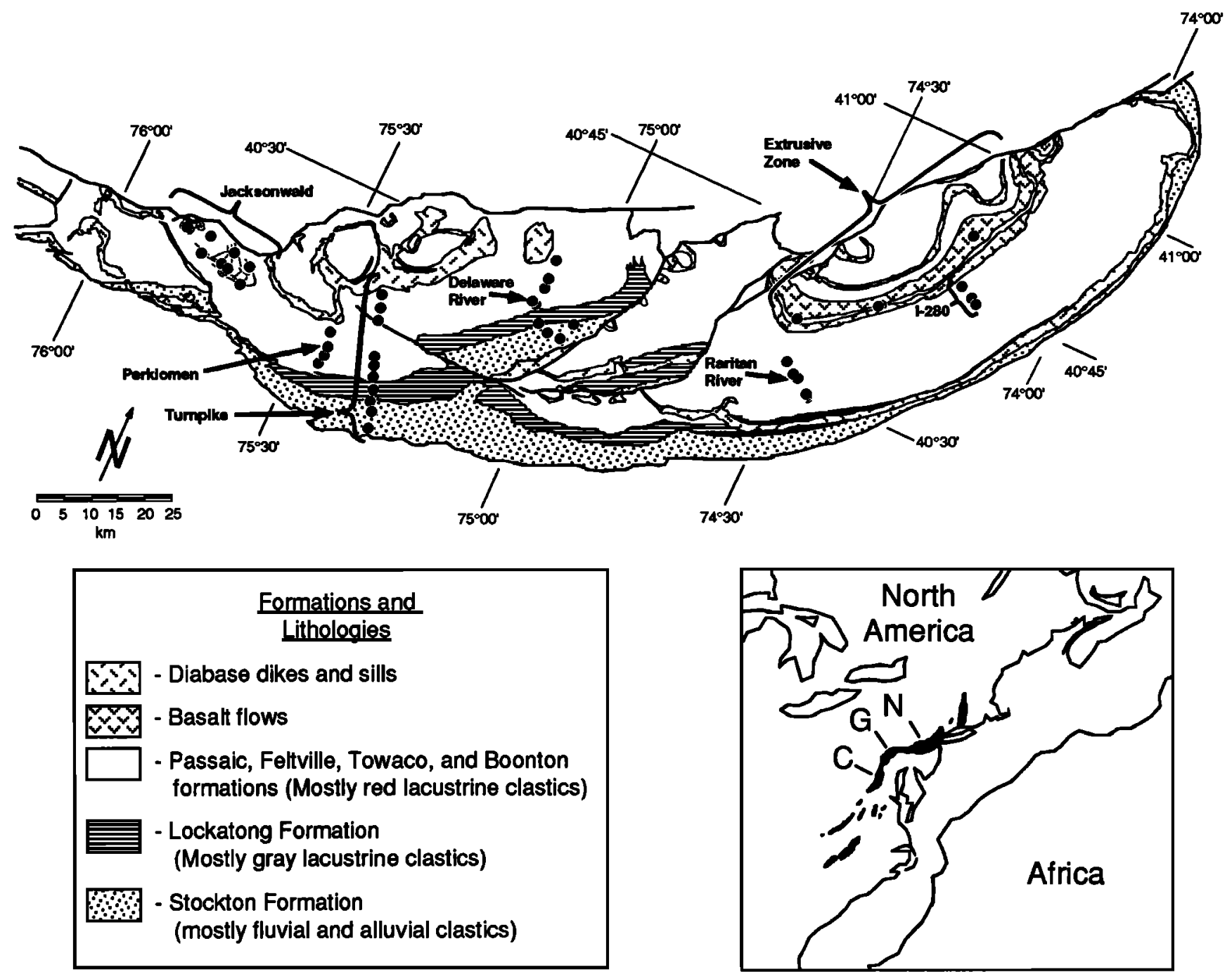

Fig. 1. Geologic sketch map of the Newark basin with generalized formation boundaries. Details of the site locations are given by Witte and Kent [1989, 1990], and Witte et al. [1991]. Inset, present continental coastlines reconstructed to their predrift configuration [Bullard et al., 1965] showing the locations of the eastem North American rift basins discussed in the text (solid areas): N, Newark basin; G, Gettysburg basin; C, Culpepper basin.

until the bedding dip direction is parallel to the fold axis (unfolding) and a rotation about a horizontal line perpendicular to the fold axis until bedding is horizontal (unplunging). The shallow plunge of the Jacksonwald syncline ensures that the order in which we apply these rotations does not significantly alter the result, although such rotations are not generally commutative.

The 15 Jacksonwald syncline B component site mean directions are significantly less dispersed without structural correction (overall mean $=358.5^{\circ} / 49.8^{\circ}, k=27$ ) than after unfolding (overall mean $=358.3^{\circ} / 32.7^{\circ}, k=12$ ) at the $95 \%$ confidence level. However, an incremental unfolding test on the $B$ component site directions yields a peak in the precision parameter at an intermediate value of unfolding (overall mean at $1 / 3$ unfolding is $359.9^{\circ} / 44.0^{\circ}, k=49$ ) that is significantly greater (at the $99 \%$ confidence level) than the full unfolding correction precision and greater (at the $90 \%$ confidence level) than the in situ precision (Figure 3). Thus, at face value, the Jacksonwald fold test indicates that the $B$ component was not acquired prior to folding at a high degree of confidence but was possibly acquired before the completion of folding. The timing of the $B$ component acquisition relative to the regional plunge remains to be addressed.

The results of this incremental fold test on the B component stand in marked contrast with results of an incremental fold test on the $\mathrm{C}$ component at virtually the same sites [Witte et al., 1991]. A set of 15 site mean $C$ component directions from the Jacksonwald syncline yielded a positive fold test, significant at the $99 \%$ confidence level, with the least dispersion achieved at virtually full unfolding (Figure 3 ). Thus the $\mathrm{C}$ component site mean directions were most likely acquired before any significant folding and thus very shortly after deposition.

\section{Tilt Test}

Nine additional sites from the I-280 and Raritan regions sampled the same middle and late Norian strata as sampled in the Jacksonwald region but in homoclinal beds with dips to the northwest of about $5^{\circ}-20^{\circ}$. All nine sites yielded at least three independently oriented estimates of the B component (Table 1). With the $26 \mathrm{~B}$ component site means from the lower and upper Newark strata [Witte and Kent, 1989, 1990], the mean direction of these 35 homoclinal sites shows no significant 

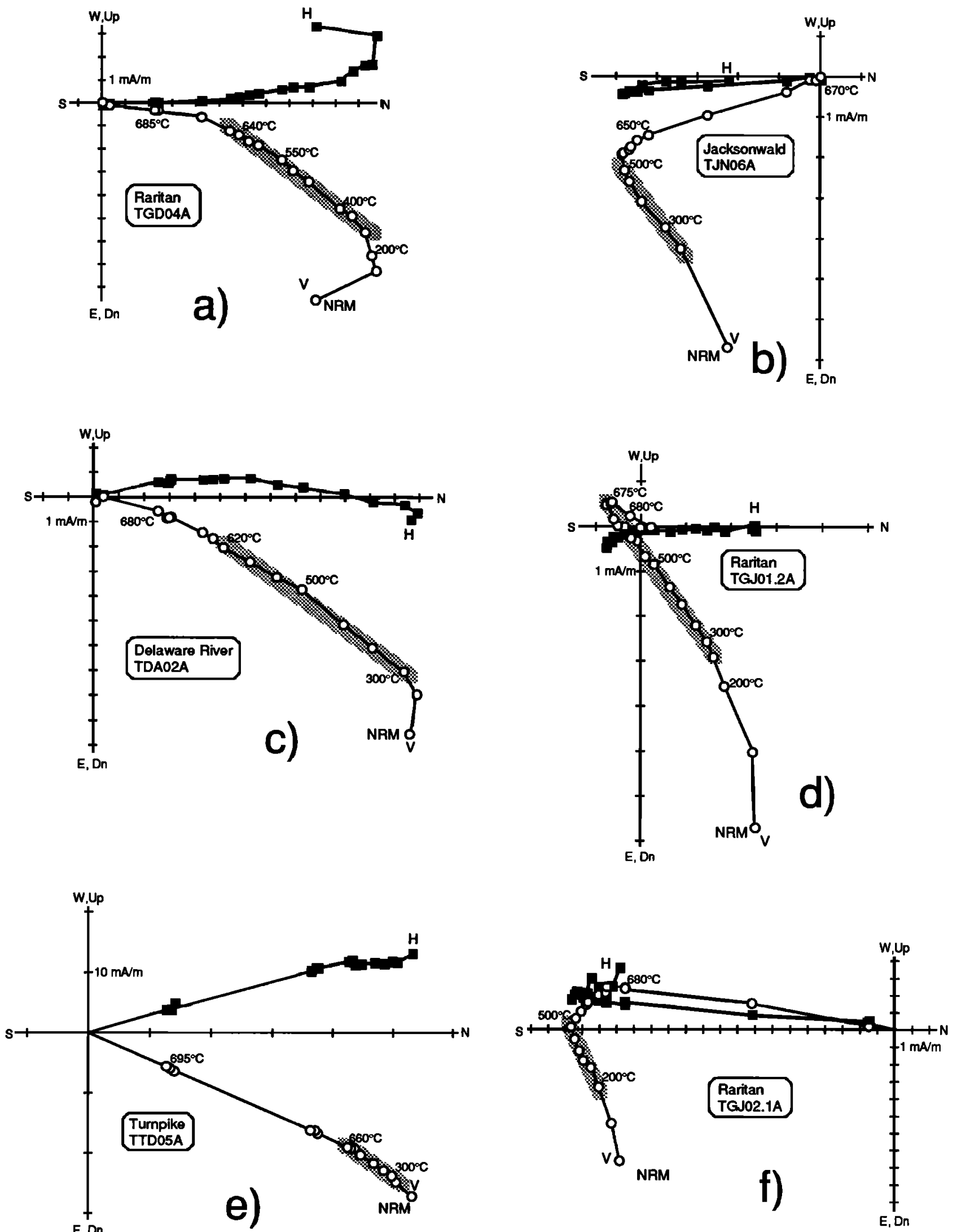

Fig. 2. Zjiderveld [1967] demagnetograms from six samples from the Passaic Fomation in the Newark basin. Open symbols are projections of vector endpoints onto the vertical north-south plane, and solid symbols are projections onto the horizontal plane, all in the geographic reference frame. B component linear trajectories are highlighted on the vertical projections by stippled lines. Demagnetograms in Figures $2 a, 2 c$, and $2 e$ show demagnetization of samples with normal polarity characteristic magnetization, and demagnetograms in Figures $2 b, 2 d$ and $2 f$ show demagnetization of samples with reversed polarity characteristic magnetizations. 
TABLE 1. B Component Site Mean Directions From Middle Newark Strata

\begin{tabular}{|c|c|c|c|c|c|c|c|c|c|c|c|}
\hline \multirow[b]{2}{*}{ Site } & \multirow[b]{2}{*}{$n$} & \multirow[b]{2}{*}{ Strike } & \multirow[b]{2}{*}{ Dip } & \multirow[b]{2}{*}{$k$} & \multirow[b]{2}{*}{$\alpha_{95}$} & \multicolumn{2}{|c|}{ Geographic } & \multicolumn{2}{|c|}{$\begin{array}{c}\text { Optimal" } \\
\text { Structural } \\
\text { Correction }\end{array}$} & \multicolumn{2}{|c|}{$\begin{array}{c}\text { Full Tilt } \\
\text { Correction }\end{array}$} \\
\hline & & & & & & D & I & $\overline{\mathbf{D}}$ & I & $\bar{D}$ & I \\
\hline $\begin{array}{l}\text { TJA } \\
\text { TJB } \\
\text { TJC } \\
\text { TJD } \\
\text { TJE } \\
\text { TJF } \\
\text { TJG } \\
\text { TJH } \\
\text { TJI } \\
\text { TJJ } \\
\text { TJL } \\
\text { TJM } \dagger \\
\text { TJN } \\
\text { TJO } \\
\text { TJP } \\
\text { TJQ } \\
\text { TJR }\end{array}$ & $\begin{array}{l}5 \\
4 \\
4 \\
4 \\
5 \\
5 \\
5 \\
4 \\
3 \\
4 \\
5 \\
3 \\
5 \\
6 \\
4 \\
5 \\
4\end{array}$ & $\begin{array}{l}278 \\
238 \\
254 \\
242 \\
153 \\
148 \\
268 \\
268 \\
291 \\
287 \\
293 \\
293 \\
108 \\
118 \\
118 \\
268 \\
280\end{array}$ & $\begin{array}{l}74 \mathrm{~N} \\
20 \mathrm{~N} \\
25 \mathrm{~N} \\
30 \mathrm{~N} \\
35 \mathrm{~W} \\
37 \mathrm{~W} \\
28 \mathrm{~N} \\
28 \mathrm{~N} \\
65 \mathrm{~N} \\
50 \mathrm{~N} \\
30 \mathrm{~N} \\
20 \mathrm{~N} \\
20 \mathrm{~S} \\
27 \mathrm{~S} \\
25 \mathrm{~S} \\
40 \mathrm{~N} \\
55 \mathrm{~N}\end{array}$ & $\begin{array}{r}25.9 \\
123.0 \\
107.8 \\
407.0 \\
98.2 \\
484.1 \\
216.7 \\
323.6 \\
239.7 \\
20.3 \\
196.1 \\
566.8 \\
35.8 \\
765.1 \\
35.0 \\
82.7 \\
44.3\end{array}$ & $\begin{array}{r}J \\
15.3 \\
8.3 \\
8.9 \\
4.6 \\
7.8 \\
3.5 \\
5.2 \\
5.1 \\
8.0 \\
20.9 \\
5.5 \\
5.2 \\
13.0 \\
2.4 \\
15.7 \\
8.5 \\
14.0\end{array}$ & $\begin{array}{r}\text { acksonwalc } \\
009.3 \\
013.4 \\
011.5 \\
005.8 \\
001.7 \\
003.1 \\
350.5 \\
018.4 \\
354.8 \\
344.5 \\
333.2 \\
335.4 \\
347.0 \\
345.5 \\
346.5 \\
357.8 \\
354.4\end{array}$ & $\begin{array}{l}\text { Regio } \\
63.4 \\
42.1 \\
46.3 \\
49.7 \\
33.2 \\
61.8 \\
57.1 \\
50.8 \\
62.7 \\
57.6 \\
40.9 \\
40.3 \\
33.8 \\
27.8 \\
26.1 \\
56.6 \\
68.8\end{array}$ & $\begin{array}{r}\boldsymbol{n} \\
009.1 \\
012.8 \\
010.8 \\
005.9 \\
001.7 \\
358.6 \\
353.8 \\
016.7 \\
000.3 \\
351.2 \\
-. . \\
-. . \\
345.9 \\
344.5 \\
345.9 \\
000.2 \\
001.8\end{array}$ & $\begin{array}{r}40.4 \\
38.0 \\
39.7 \\
43.3 \\
40.9 \\
70.5 \\
49.4 \\
42.2 \\
42.6 \\
43.4 \\
-. . \\
-. . \\
39.4 \\
35.1 \\
33.0 \\
45.1 \\
51.8\end{array}$ & $\begin{array}{l}008.3 \\
004.4 \\
004.0 \\
355.0 \\
334.2 \\
289.2 \\
353.4 \\
012.1 \\
009.1 \\
359.6 \\
345.5 \\
344.3 \\
336.2 \\
329.6 \\
333.4 \\
358.1 \\
006.5\end{array}$ & $\begin{array}{r}-10.7 \\
26.8 \\
23.5 \\
23.1 \\
42.8 \\
60.1 \\
29.2 \\
23.9 \\
0.3 \\
11.2 \\
19.0 \\
25.7 \\
50.0 \\
45.2 \\
42.9 \\
16.6 \\
15.8\end{array}$ \\
\hline $\begin{array}{l}\text { TGA } \\
\text { TGC } \\
\text { TGD } \\
\text { TGE } \\
\text { TGF } \\
\text { TGJ } \\
\text { TGG } \\
\text { TGH } \\
\text { TGI }\end{array}$ & $\begin{array}{l}6 \\
4 \\
5 \\
5 \\
5 \\
9 \\
5 \\
4 \\
4\end{array}$ & $\begin{array}{l}228 \\
228 \\
230 \\
218 \\
236 \\
230 \\
231 \\
222 \\
239\end{array}$ & $\begin{array}{l}12 \mathrm{~N} \\
11 \mathrm{~N} \\
10 \mathrm{~N} \\
13 \mathrm{~W} \\
16 \mathrm{~N} \\
13 \mathrm{~N} \\
11 \mathrm{~N} \\
07 \mathrm{~W} \\
09 \mathrm{~W}\end{array}$ & $\begin{array}{r}R \\
85.6 \\
28.0 \\
96.7 \\
42.9 \\
53.2 \\
26.2 \\
127.6 \\
36.2 \\
12.2\end{array}$ & $\begin{array}{r}\text { aritan } \\
7.3 \\
17.7 \\
7.8 \\
11.8 \\
10.6 \\
10.2 \\
6.8 \\
15.5 \\
27.4\end{array}$ & $\begin{array}{c}\text { River and } \\
001.2 \\
349.4 \\
358.2 \\
359.4 \\
012.3 \\
351.3 \\
002.7 \\
001.5 \\
017.9\end{array}$ & $\begin{array}{r}I-280 \\
41.3 \\
40.8 \\
34.6 \\
41.7 \\
48.0 \\
51.8 \\
37.6 \\
35.6 \\
53.2\end{array}$ & $\begin{array}{r}\text { egions } \\
001.2 \\
349.4 \\
358.2 \\
359.4 \\
012.3 \\
351.3 \\
002.7 \\
001.5 \\
017.9\end{array}$ & $\begin{array}{l}41.3 \\
40.8 \\
34.6 \\
41.7 \\
48.0 \\
51.8 \\
37.6 \\
35.6 \\
53.2\end{array}$ & $\begin{array}{l}355.4 \\
345.4 \\
354.6 \\
351.8 \\
002.8 \\
345.9 \\
358.1 \\
358.1 \\
010.4\end{array}$ & $\begin{array}{l}32.1 \\
31.3 \\
26.6 \\
33.0 \\
35.8 \\
40.7 \\
29.1 \\
30.8 \\
46.8\end{array}$ \\
\hline Al1 & 24 & & & liddle & (2) & $\begin{array}{r}\text { Mean } B \\
359.5 \\
k= \\
\alpha_{95}=\end{array}$ & $\begin{array}{l}\text { Compo } \\
47.2 \\
35,\end{array}$ & $\begin{array}{r}n \text { Dire } \\
000.4 \\
k= \\
\alpha_{95}=\end{array}$ & $\begin{array}{l}43.7 \\
59 \\
9\end{array}$ & $\begin{array}{r}354.7 \\
k= \\
\alpha_{95}=\end{array}$ & $\begin{array}{l}30.4 \\
16, \\
7.7\end{array}$ \\
\hline
\end{tabular}

$n$ is number of samples for calculation of site mean direction (number of sites for overall mean), $k$ is the best estimate of Fisher's precision parameter, $\alpha_{95}$ is the radius of the $95 \%$ confidence circle, D is declination in degrees, $I$ is inclination in degrees.

"The optimal structural correction consists of a $34 \%$ unfolding with no unplunging f.r the Jacksonwald syncline sites and no untilting for the homoclinal Raritan River and I-280 sites.

tInadequate constraint on local plunge prevented optimal structural corrections for these sites; these sites were thus excluded from the calculation of the means.

change in dispersion from in situ $\left(003.9^{\circ} / 40.5^{\circ}, k=71\right)$ to tiltcorrected $\left(358.3^{\circ} / 32.2^{\circ}, k=70\right)$ coordinates, reflecting the more or less uniform shallow bedding dips.

There is a difference of $\sim 25^{\circ}$ between the azimuth of dip in the homoclinal Newark basin and the azimuth of plunge in the Jacksonwald syncline. If the optimally unfolded (by 1/3) B component mean direction from the Jacksonwald syncline $\left(359.9^{\circ} / 44.0^{\circ}, k=49\right)$ is unplunged (either by a uniform $13^{\circ}$ unplunging or by unplunging each site until bedding is horizontal), it diverges from the B component mean direction from the homoclinal sites as they are similarly untilted (Figure 4). The homoclinal and Jacksonwald means show no significant difference in direction before any tilt or plunge corrections $\left(\gamma_{0}=5^{\circ}, \gamma_{c}=6^{\circ}\right.$, where $\gamma_{0}$ is the observed angular difference between the means of the two subsets and $\gamma_{c}$ is the critical angle at which we can reject the null hypothesis of a common mean direction at the $95 \%$ confidence level [McFadden and Lowes, 1981; McFadden and McElhinny, 1990]) but the difference is significant at full untilting/unplunging $\left(\gamma_{0}=10^{\circ}\right.$, $\gamma_{c}=6^{\circ}$ ). If this test is performed on site VGPs we obtain the same result: the means of the two VGP subsets are indistinguishable before any tilt or plunge correction $\left(\gamma_{0}=5^{\circ}\right.$, $\left.\gamma_{c}=6^{\circ}\right)$, whereas the means are statistically distinct $\left(\gamma_{0}=9^{\circ}, \gamma_{c}\right.$ $=5^{\circ}$ ) after untilting/unplunging. Thus the tilt test indicates the B component was most likely acquired after tilting and plunging. Similarly, the fold test discussed above indicates that the B component was acquired after most, if not all, of the folding.

\section{Variation in Remagnetization Direction}

The $\mathrm{B}$ component of magnetization displays a remarkable consistency in direction throughout the Newark basin. The $\mathbf{5 0}$ B component sites mean directions, with what we regard as the optimal structural correction (one-third unfolding, no untilting or unplunging), yield an overall mean direction of $002.8^{\circ} / 41.6^{\circ} \quad\left(k=61, \alpha_{95}=2.6^{\circ}\right)$ (Figure 5). If the B component mean direction from middle Newark sites from the northern part of the basin (including the Raritan and I-280 sites with an overall mean of $001.2^{\circ} / 43.0^{\circ}, k=77, \alpha_{95}=5.9^{\circ}, N=9$ ) is compared with the $B$ component mean direction from middle Newark sites from the southern part of the basin (the Jacksonwald syncline with an overall mean of $359.9^{\circ} / 44.0^{\circ}, k$ 

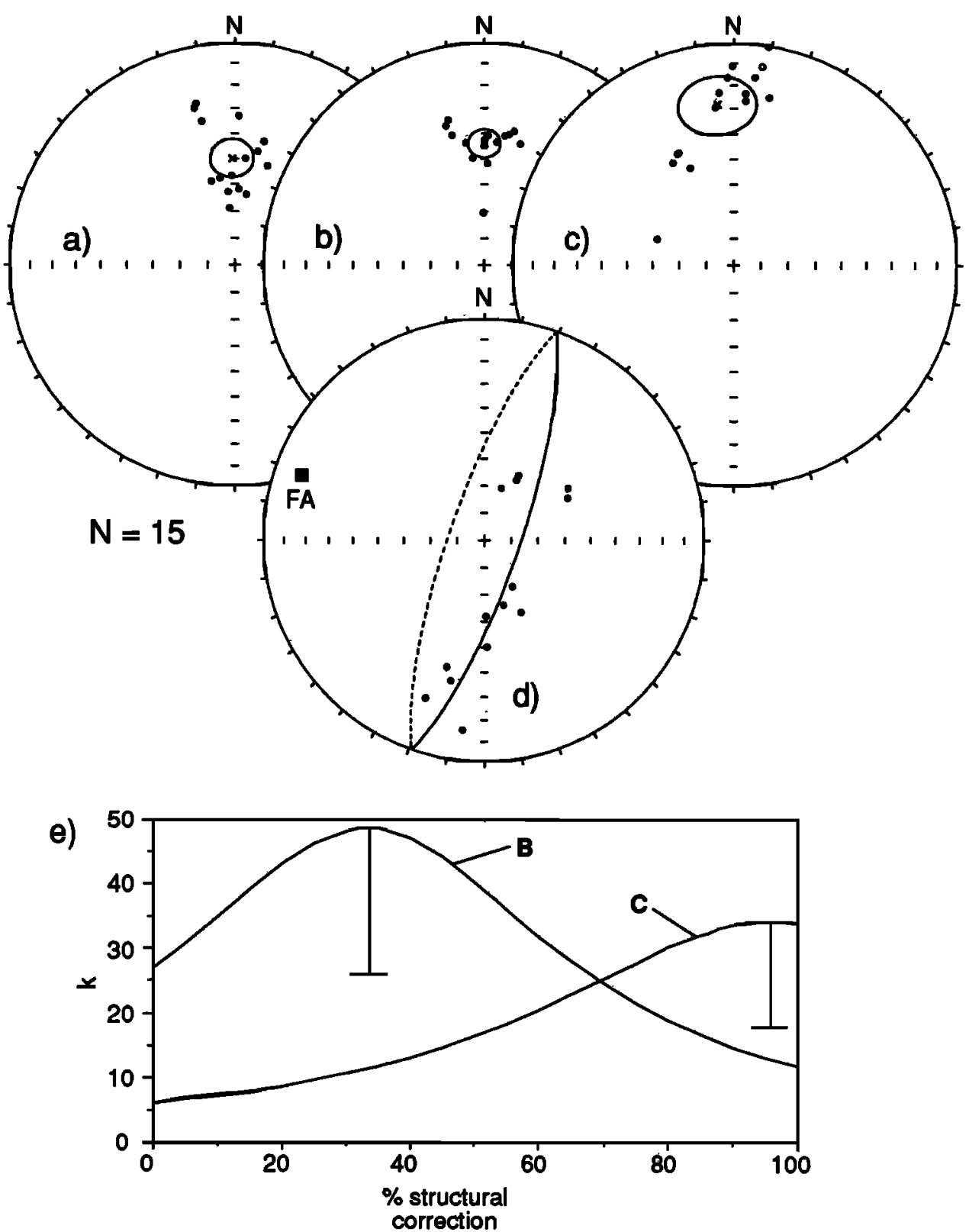

Fig. 3. Jacksonwald syncline fold test. Solid (open) circles indicate downward (upward) directed directions on equal area stereographic projections (Figures $3 a-3 d$ ). Cross with ellipse indicates the overall mean of sites and its $\alpha_{95}$ envelope. (a) B component site mean directions in geographic coordinates. (b) B componènt site mean directions after $1 / 3$ unfolding about the Jacksonwald fold axis (and no unplunging). (c) B component directions with full tilt correction (rotation of bedding to horizontal about present strike). (d) Poles to bedding at the 15 sites from the Jacksonwald syncline; great circle indicates least-squares fit to these bedding poles and the square indicates the fold axis (FA). (e) Incremental fold test on the B and C components at 15 sites in the Jacksonwald syncline. Variation in best estimates of Fisher's [1953] precision parameter $k$ is plotted against percent structural correction which for $B$ is unfolding without unplunging but for $C$ is rotation of bedding to horizontal about the present strike (discussed by Witte et al., [1991]). Vertical lines indicate the 95\% confidence intervals on the precision parameter for each curve.

$=49, \alpha_{95}=5.5^{\circ}, N=15$ ), one sees no significant difference in these two subsets of $B$ component directions. Likewise, if the B component mean direction from lower Newark sites (including the Delaware River, Pennsylvania Turnpike, and Perkiomen Creek sites with an overall mean of $005.0^{\circ} / 40.4^{\circ}, k$ $=66, \alpha_{95}=3.8^{\circ}, N=22$ ) is compared with the B component mean direction from upper and middle Newark sites (the extrusive zone, Raritan, I-280, and Jacksonwald sites with an overall mean of $001.0^{\circ} / 42.5^{\circ}, k=59, \alpha_{95}=3.6^{\circ}, N=28$ ), one also sees no significant difference in the two subsets of $B$ component directions. The lack of significant difference in the
B component magnetization directions from different geographic regions or different stratigraphic levels within the basin argues against any differential post-remagnetization tectonic rotations between the regions we have sampled. This observation is consistent with the general coherency of the $\mathrm{C}$ component directions from the Newark basin [Witte et al, 1991]. Furthermore, the general parallelism of the Newark rift basin border fault with local Precambrian basement structures [e.g., Ratcliffe and Burton, 1985; Swanson, 1986] argues against wholesale rotation of the basin with respect to cratonic North America. 
There is, however, a small variation in the uniformly normal polarity $B$ component that is dependent on the polarity of the C component characteristic magnetization. The mean of the $B$ component site directions at sites with a normal polarity $\mathbf{C}$

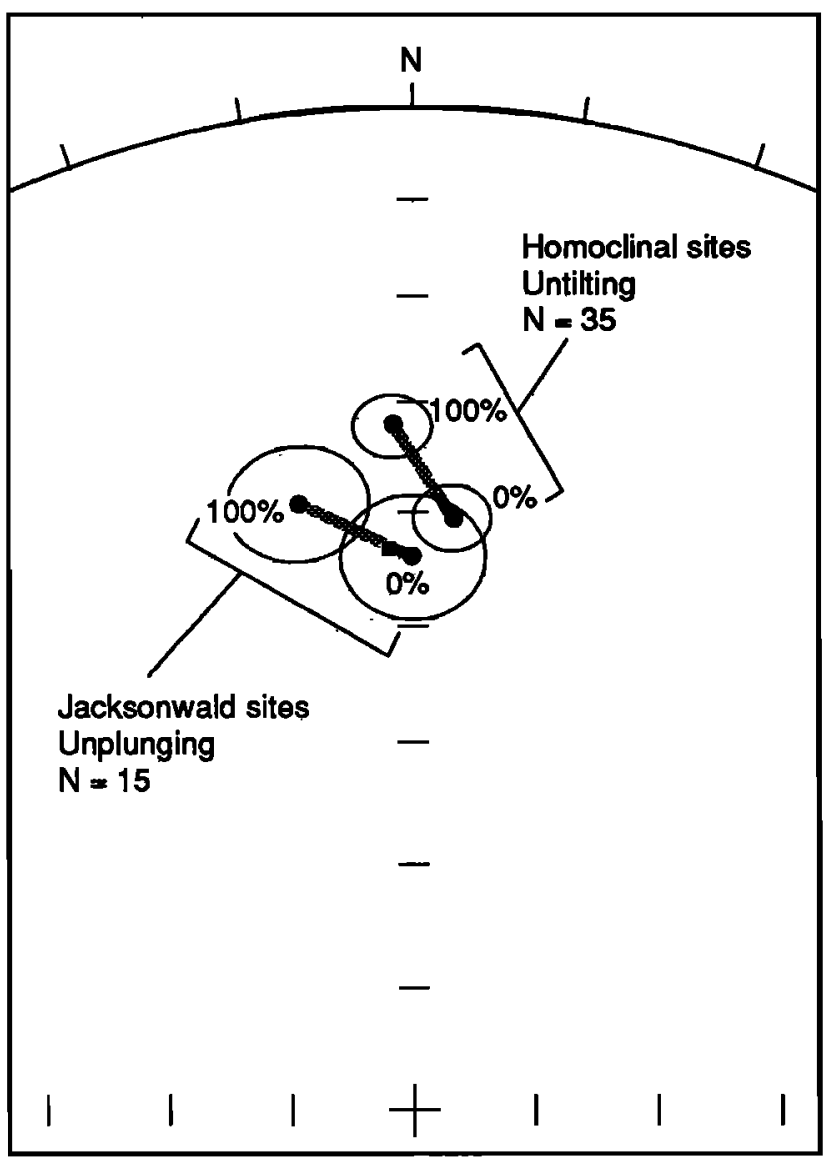

component $\left(003.5^{\circ} / 38.0^{\circ}, k=77, \alpha_{95}=3.3^{\circ}, N=25\right)$ is $7^{\circ}$ $\pm 5^{\circ}$ shallower than the mean of the $B$ component site directions at sites with a reversed polarity $\mathrm{C}$ component $\left(001.4^{\circ} / 45.2^{\circ}, k=62, \alpha_{95}=4.0^{\circ}, N=22\right)$. A similar bias in the $B$ component was noted in the lower Newark subset [Witte and Kent, 1989] and attributed to a small residual contamination by the $C$ component characteristic magnetization (a phenomenon described as "underprinting" by Miller and Kent [1988]). However, any bias of the B component direction should be cancelled if the contamination from normal and reversed polarity characteristic magnetizations is similar. Indeed, the preferred mean $B$ component direction $\left(002.8^{\circ} / 41.7^{\circ}, N=50\right)$ differs by less than $1^{\circ}$ from the $B$ component mean of the normal and reversed characteristic polarity subsets $\left(002.5^{\circ} / 41.6^{\circ}, N=2\right)$.

\section{Variation in Remagnetization Intensity}

The small, but measurable, dependence of the $B$ component direction on the polarity of the $\mathrm{C}$ component implies that there is some overlap in the unblocking spectra of these components. To compare the relationship between the two thermal unblocking spectra, we calculated demagnetization graphs for the $B$ and $C$ magnetization components in representative samples by a method similar to that described by

Fig. 4. Lower hemisphere equal-area stereographic projection of overall site mean directions and associated confidence circles for $B$ component directions isolated from 15 Jacksonwald sites and 35 homoclinally dipping Newark siles. The means of these two subsets are plotted before $(0 \%)$ and after $(100 \%)$ plunge or tilt correction and are connected by the traces of the mean directions with intermediate untilting/unplunging corrections. The solid square indicates the overall site mean direction of 15 Jacksonwald sites after a single step unfolding of $1 / 3$ of the present bedding tilt (using a rotation about present strike). Above $25 \%$ tilt correction (light lines) the subset directions are statistically distinct at the $95 \%$ confidence level.

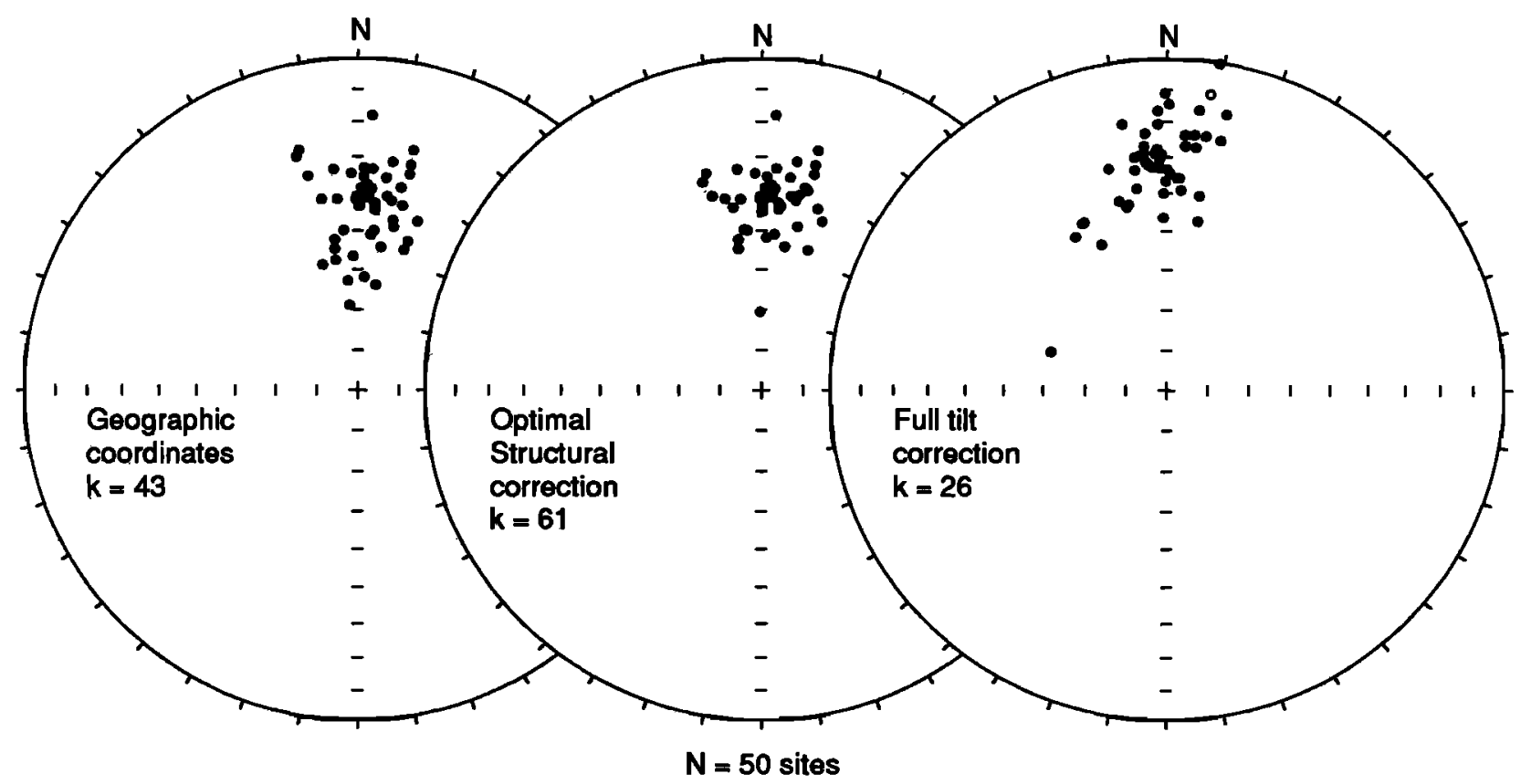

Fig. 5. Equal-area stereographic projections of the 50 reliable B component site mean directions in geographic coordinates (left), after optimal structural correction (middle), and after full tilt correction (right). The optimal structural correction was determined to consist of $1 / 3$ unfolding about the fold axis in the Jacksonwald region and no unplunging/untilting throughout the basin. 
Zijderveld [1967]. In this application, the vector at each demagnetization step at $300^{\circ} \mathrm{C}$ and above was resolved into components parallel to the PCA estimates of the B and C magnetization directions. Figure 6 demonstrates this relationship for a sample with a reversed polarity $\mathrm{C}$ component; samples with normal polarity $\mathrm{C}$ components gave similar but noisier results.

The analysis confirms and further quantifies what one would already suspect from a qualitative examination of the demagnetization diagrams: The $B$ component is unblocked over a wide temperature range from $300^{\circ} \mathrm{C}$ to about $650^{\circ} \mathrm{C}$, whereas the $\mathrm{C}$ component is primarily unblocked over a discrete temperature range from about $660^{\circ} \mathrm{C}$ to $690^{\circ} \mathrm{C}$ (Figure 6). Thus, the $B$ and $C$ components of magnetization differ not only in their directions of magnetization and their maximum unblocking temperatures but also in the character and width of their unblocking spectra. A slight demagnetization of the $\mathrm{C}$ component over the unblocking temperature range of the $B$ component leads to the underprinting; the virtually complete decay of the $\mathrm{B}$ component before the discrete unblocking interval of the $\mathrm{C}$ component indicates a negligible overprint contamination, as suggested by the positive reversal test on the C component [Witte et al., 1991].

We also estimated the absolute intensities of the $B$ and $C$ components for those samples whose demagnetization curves demonstrated both linear $\mathbf{B}$ and $\mathbf{C}$ component trajectories. Demagnetization trajectories such as shown in Figure $2 f$ were not used because significant overlap between the magnetization unblocking spectra of the two components made it difficult to accurately estimate the intensity of the B and C components. The relative intensities of the $B$ and $C$ components show a wide range of variation even within a single site (Figure 7a). In general, the intensities of the two components are very similar, however, the $\mathrm{C}$ component intensity has a slightly larger range than the $B$ component. Aside from the anomalously large B component in the Delaware River region (Figure $7 b$ ), there seems to be little systematic variation in the $B$ component intensity throughout the geographic or stratigraphic extent of the basin.

The lack of any consistent correlation, either direct or inverse, between the $\mathbf{B}$ and $\mathbf{C}$ component intensities points to independent origins of the magnetizations, where the $B$ component magnetization can be regarded more as an addition, or an overprint rather than a replacement or resetting of the preexisting $\mathbf{C}$ component. Nevertheless, the high maximum unblocking temperatures of both the $B$ (up to $650^{\circ} \mathrm{C}$ ) and $\mathrm{C}$ (up to $680^{\circ} \mathrm{C}$ ) components suggest that hematite is the predominant magnetic mineral in the red beds and the carrier of both components. The smoothness of the isothermal remanent magnetization (IRM) acquisition curve, with a lack of saturation below 1.5 $T$ (Figure 8), and the thermal demagnetization of IRM curve [Witte and Kent, 1989] also indicate that remanence is carried by a single magnetic phase. For example, no evidence for lower coercivity and unblocking temperature magnetite is observed. Thus it seems that the range in unblocking temperatures observed in these rocks is likely related to variation in some physical property, such as grain size, of the hematite. Similar to the observations reported by McIntosh et al. [1985], we observe hematite as a very fine grained $(<5 \mu \mathrm{m})$ interstitial pigment and also as larger (up to $50 \mu \mathrm{m}$ ) but rare, specular grains in thin and polished sections. A tentative interpretation for the different unblocking spectra of the $B$ and $C$ components, following the model of Irving and Opdyke [1965], is that the thermally distributed B component magnetization is associated with finer grained hematite, whereas the thermally discrete $\mathbf{C}$ component
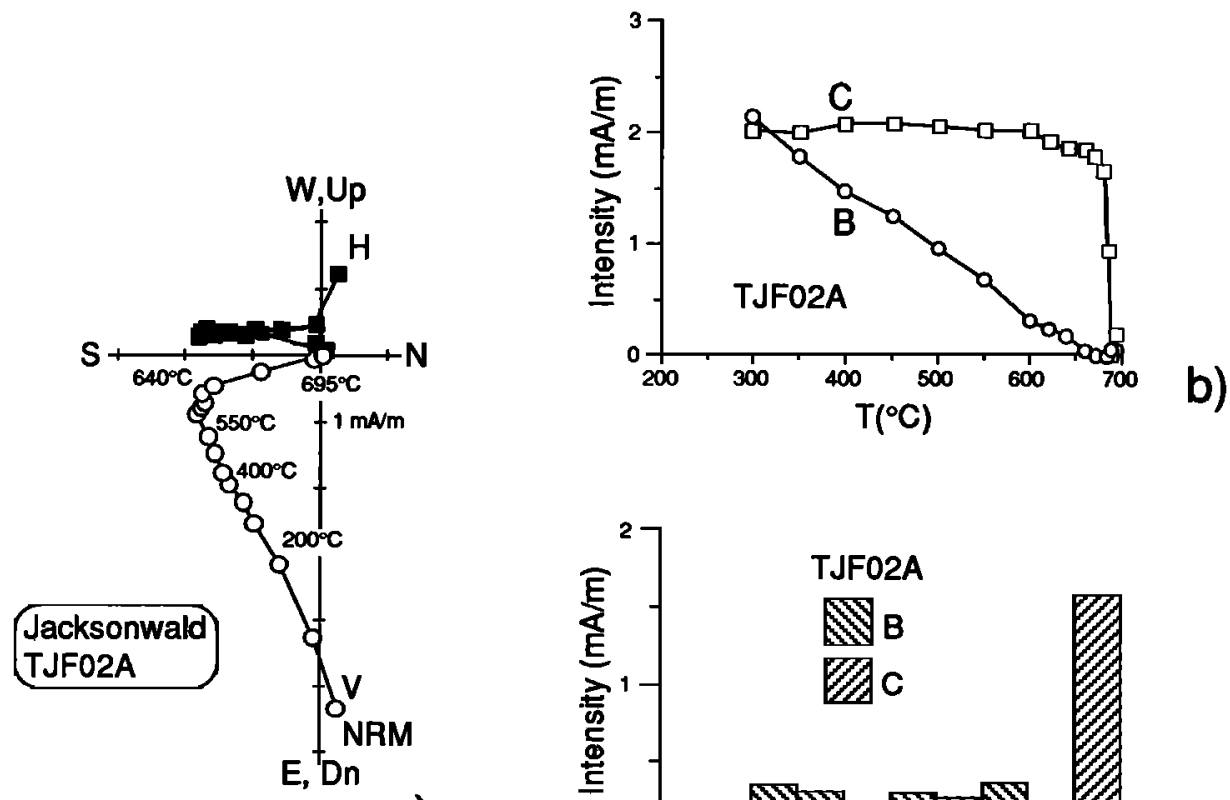

a)

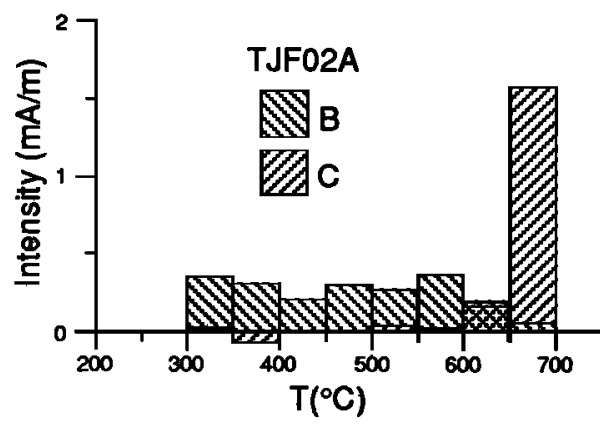

Fig. 6. Thermal demagnetization of a representative middle Newark red bed specimen from the Passaic Formation. (a) Zjiderveld demagnetogram indicating vector endpoints in geographic coordinates; open symbols are projections onto the vertical north-south plane, and solid symbols are projections onto the horizontal plane. (b) Demagnetization graphs calculated for the $\mathrm{B}$ and $\mathrm{C}$ components as described in the text. (c) Histograms of magnetizations unblocked in $50^{\circ} \mathrm{C}$ intervals for the $B$ and $C$ components. 

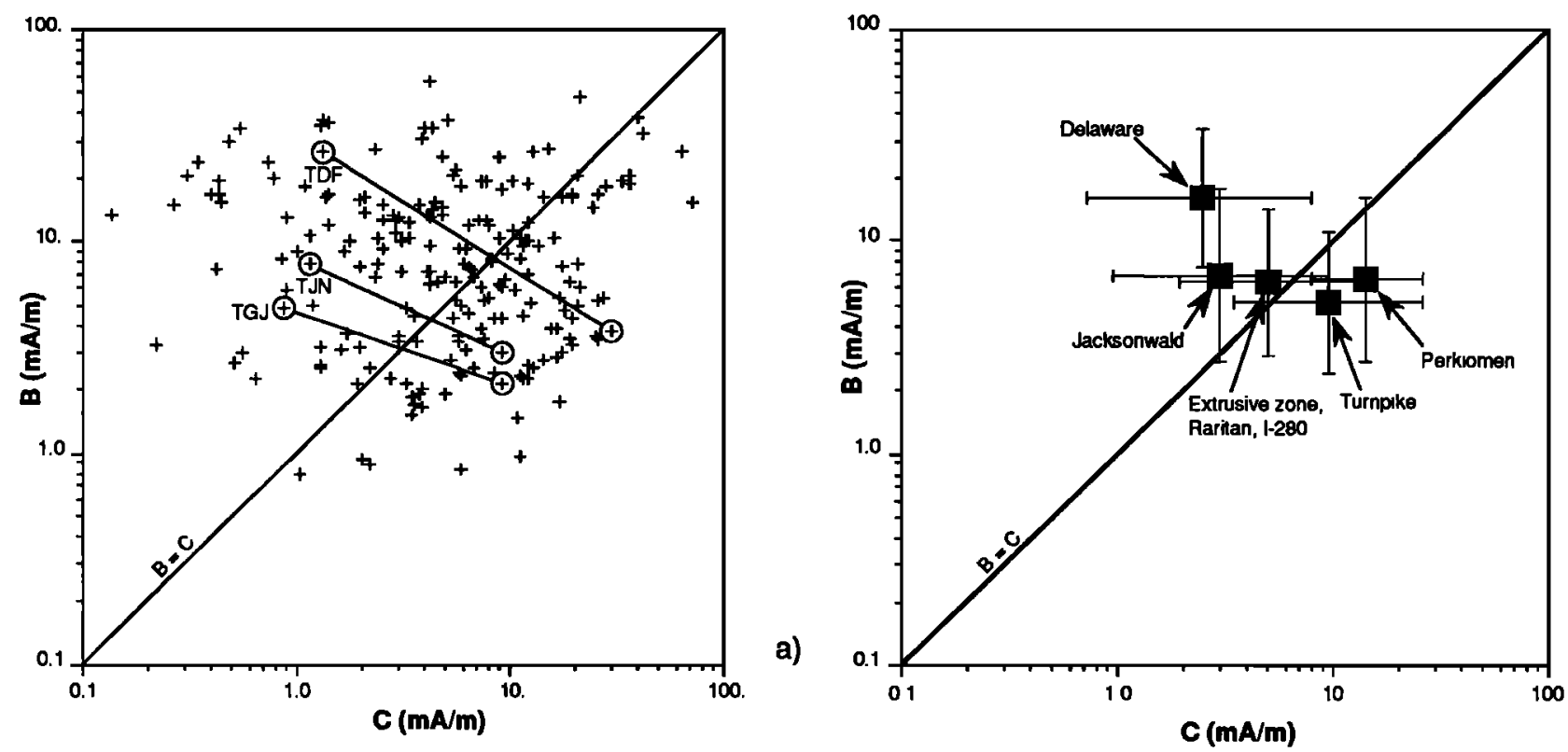

b)

Fig. 7. Intensity of the B component remanence versus the intensity of the $\mathrm{C}$ component remanence. (a) Component intensities from 207 samples of Newark basin red beds, showing the lack of any systematic correlation even for samples from the same site (e.g., TGJ, TJN, and TDF). (b) Log-mean and standard deviation of B and C component intensities according to geographic groupings of sites in the Newark basin as defined in Figure 1.

magnetization may be preferentially carried by somewhat coarser hematite grains. Theoretical support for such a grain size dependence of unblocking temperature is provided by Dodson and McClelland-Brown [1980].

\section{AGE OF REMAGNETIZATION}

Folds in the eastern North American Mesozoic rift basins, such as the Jacksonwald syncline in the Newark basin, are invariably associated with either the normal border faults (as is the case in the Jacksonwald region where Mesozoic sediments are faulted against Precambrian and Paleozoic basement rocks) or normal internal faults (in these cases the hanging wall is most commonly folded) [Lyttle and Epstein, 1987; Olsen et al., 1989]. Each such fold decreases in amplitude with distance from its associated fault, suggesting that the folding was directly associated with slip on the normal faults. In the Jacksonwald syncline, stratigraphic thickness and facies relations in the cyclic lacustrine sediments indicate that folding of the strata was probably initiated penecontemporaneously with deposition and related to subsidence along the border fault [Olsen et al., 1989]. Although the initiation of this folding and the tilting associated with subsidence is probably nearly syndepositional, cessation of folding and tilting is less tightly constrained.

The youngest preserved strata in the Newark basin (the Boonton Formation of Hettangian age) are folded, but Cretaceous coastal plain deposits (which overlie tilted strata in parts of the Newark basin at the surface) are not deformed. In the offshore rift basins of the Baltimore Canyon and Georges Bank regions the oldest sediments above the postrift unconformity are at least Middle Jurassic in age [Klitgord et al., 1988], indicating that subsidence in the rift basins was largely complete by the Middle Jurassic. Thus the tilting of the Newark strata was certainly completed by the Cretaceous and if the structural development of the Newark basin was analogous to the offshore rift basins, then the folding and tilting of the Newark strata is constrained to end by the Middle Jurassic.
The B component magnetization in the Jacksonwald syncline achieves the tightest clustering with at most partial (1/3) unfolding. This implies that this magnetization was not acquired before folding but may have been acquired during the late stages of folding. An apparently "synfolding" magnetization may in some instances result from strain modification of a pre-folding magnetization [Stamatakos and Kodama, 1990]. However, the positive fold test on the coexisting $\mathbf{C}$ component from these same sites, with its peak in precision very near full unfolding, leads us to believe that penetrative strain has not significantly modified the remanent magnetization of these rocks.

The other pertinent tectonic feature in the Newark basin is the ubiquitous $5^{\circ}-20^{\circ}$ dip down toward the border faults. This tilt was probably acquired during subsidence in the basin as a result of dip slip on normal faults [e.g., White et al., 1986]. Assuming that the northwesterly tilt of the homoclinal beds throughout the northern and central parts of the basin is related

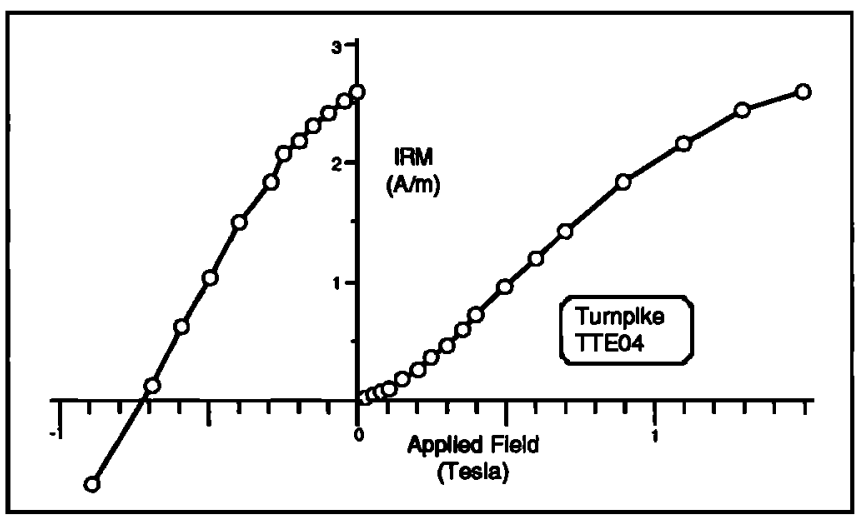

Fig. 8. IRM acquisition curve and backfield experiment for a typical red bed specimen from the Passaic Formation indicating that saturation IRM is not achieved by $1.5 \mathrm{~T}$ and remanent coercivity is at least $0.7 \mathrm{~T}$, properties that are attributed to hematite. 
to the west-northwesterly plunge of the Jacksonwald syncline, the statistically significant divergence of the B component mean directions from these areas with increasing tilt and plunge correction indicates acquisition late in the deformation history of the strata, after all tilting/plunging was complete and after folding was two thirds or more complete.

The site mean directions of the $B$ component expressed as virtual geomagnetic poles (VGPs) yield a mean paleomagnetic pole at $74^{\circ} \mathrm{N}, 96^{\circ} \mathrm{E}\left(k=63, A_{95}=2.6^{\circ}, N=50\right)$ after optimal structural correction. From constraints which are available on the age of folding and the observation that the $\mathrm{B}$ component magnetization may be synfolding, the age of this paleomagnetic remagnetization pole is constrained to the Jurassic.

Perhaps the tightest constraint on the age of the $B$ component acquisition can be inferred from comparison of the $B$ component remagnetization pole with the N2 pole of Smith and Noltimier [1979]. As argued in the introduction, field relations, radiometric age data, and comparison with other North American reference poles strongly suggest that the N2 pole represents a secondary magnetization. Indeed, many of the $\mathrm{N} 2$ rocks seem to have suffered a hydrothermal resetting of their K/Ar systems at about $175 \mathrm{Ma}$ [Sutter, 1988], and it seems reasonable to take this as the age of the $\mathrm{N} 2$ remagnetization. Half of the site mean VGPs (78 of 156) that go into the N2 compilation come from the Gettysburg, Yorkhaven, Birdsboro, and Quakertown diabase intrusions of the Newark and Gettysburg basins and have been corrected for tilt [Beck, 1972]. This subset of the N2 compilation, not surprisingly, yields a paleomagnetic pole at middle latitudes $\left(64^{\circ} \mathrm{N}, 103^{\circ} \mathrm{E}\right)$, within $2^{\circ}$ of the $\mathrm{N} 2$ pole $\left(65^{\circ} \mathrm{N}, 103^{\circ} \mathrm{E}\right)$ (Figure 9). However, if the N2 magnetization in the diabase intrusions was acquired in the Middle Jurassic $(\sim 175 \mathrm{Ma})$, as previous interpretations have suggested [Smith and Noltimier, 1979; Gordon et al., 1984; May and Butler, 1986], then the diabase magnetization should postdate the onset of folding and tilting in the Triassic host rocks by at least $\mathbf{2 5} \mathrm{m}$.y. It follows that some, if not all, of the folding and tilting of the diabase bodies was most likely accomplished before the acquisition of the N2 magnetization. On this basis alone, full tilt correction is unwarranted.

The $B$ component and N2 diabase magnetizations were therefore both apparently acquired late in the deformation history of the Newark (or Gettysburg) basins. The B component magnetization $\left(74^{\circ} \mathrm{N}, 96^{\circ} \mathrm{E}\right.$, after optimal structural correction) and the $\mathrm{N} 2$ magnetization $\left(73^{\circ} \mathrm{N}, 66^{\circ} \mathrm{E}\right.$, using the Beck [1972] subset without tilt correction) yield similar highlatitude pole positions, differing by only $9^{\circ}$. The similarity of the pole positions and uniform normal polarities of the $B$ and N2 magnetizations lead us to conclude that they were acquired at about the same time, most likely during the $\sim 175 \mathrm{Ma}$ hydrothermal event. The difference between the N2 and B component paleopoles may in part be attributed to the $\mathrm{N} 2$ magnetization being acquired before folding of the intrusions was completed, as is the case of the $B$ component, or incomplete isolation of the $\mathrm{N} 2$ magnetization direction by the low (15 mT) blanket AF treatment used [Beck, 1972]. Further study of the composition of the diabase intrusion magnetization and the relationships between the acquisition of the magnetization component(s) and structural deformation could possibly resolve these uncertainties. From the available information, we regard the tilt-corrected N2 pole position as invalid and the in situ N2 pole position as suspect. Nevertheless, we regard Sutter's [1988] $\sim 175$ Ma determination of the age of the hydrothermal episode which reset the K-Ar system in the intrusions to be a good estimate of the age of the $B$ component remagnetization.

\section{REMAGNETIZaTtON MECHANISM}

Owing to the high unblocking temperatures observed for the B component (extending upwards to $650^{\circ} \mathrm{C}$, Figure 6), thermoviscous acquisition by hematite would demand implausibly high temperatures, of the order $600^{\circ} \mathrm{C}$, even if the thermal event was sustained for an extended geological time interval [Pullaiah et al., 1975; Kent and Miller, 1987]. The lack of any evidence of regional high temperature alteration of the red beds, except in hornfels in the very immediate vicinity $(<100 \mathrm{~m})$ of the diabase intrusions, thus indicates that the red bed remagnetization process most likely involved the chemical precipitation or alteration of hematite rather than a thermoviscous resetting of existing hematite. Furthermore, the difference between the $\mathrm{C}$ component of the upper Newark (extrusive zone) and the $B$ component poles indicates that the widespread chemical overprinting of the Newark basin red beds is not temporally associated with the Hettangian ( $200 \mathrm{Ma}$ ) episode of igneous activity which saw the volumetrically large intrusion of diabase and extrusion of tholeiite in and around the Newark Supergroup basins [deBoer et al., 1988]. Instead, it appears that the $175 \mathrm{Ma}$ hydrothermal event responsible for the resetting of the ages in the intrusions [Sutter, 1988] and magnetic overprinting of the sediments and intrusions postdates this igneous activity by some $25 \mathrm{~m} . \mathrm{y}$.

A constraint on the upper limit of the time necessary for the acquisition of the $B$ component is provided by the lack of any indication of APW in the B component directions or poles. Although the details of the Jurassic position of APW for North America are still debatable, there is general agreement that the Jurassic APW path must have traced out an arc of at least $30^{\circ}$ at a minimum average rate of about $0.5^{\circ} / \mathrm{m}$.y. (e.g., J1 to $\mathrm{J} 2$ track of May and Butler [1986]). Thus one would expect that the B component directions should be perceptibly streaked, or have an elliptical distribution, if the $B$ component remagnetization sampled as much as $\sim 15 \mathrm{~m}$.y. of North American APW; however, the distribution of site mean directions is not statistically distinct from Fisherian at the $95 \%$ confidence level. Further support for a rather rapid acquisition of the B component is its uniform polarity. Over most of the Jurassic, geomagnetic polarity was apparently mixed with several relatively long (1-3 m.y.) normal polarity chrons and many considerably shorter magnetochrons [Ogg and Steiner, 1984. Thus the observed uniform normal polarity of the B component magnetizations that we have consistently isolated from the Newark basin red beds suggests that basin-wide remagnetization was accomplished in not much more than a few million years. A remagnetization event on this time scale is compatible with a hydrothermal/chemical process which depends on paleohydrological mass transfer instead of the relatively slow process of thermal conduction.

Further insight into the remagnetization mechanism comes from the relative dispersion of the component directions. The within-site precision of the $B$ component magnetization directions (typically $k=50$ to 500 ) is greater than the withinsite precision of the $\mathrm{C}$ component directions (typically $k=10$ to 100). Furthermore, the between-site precision of the $B$ component site mean directions $(k=63, N=50$ sites $)$ is significantly greater than that of the $\mathrm{C}$ component site means ( $k=34, N=53$ sites; [Witte et al., 1991]). The high level of precision observed in the remagnetization directions might, 
rather implausibly, be the result of a very rapid acquisition process, such that sites from throughout the basin simultaneously captured a relatively brief (less than $\sim 1$ kyr) interval of secular variation. More likely, the B component was acquired over a relatively longer interval than the $C$ component at the site level (if not the sample level) such that each site (or even each sample) averaged secular variation more effectively than in the case of the $\mathrm{C}$ component.

Widespread remagnetization in eastern North America is also documented in Paleozoic red beds of the Appalachians during

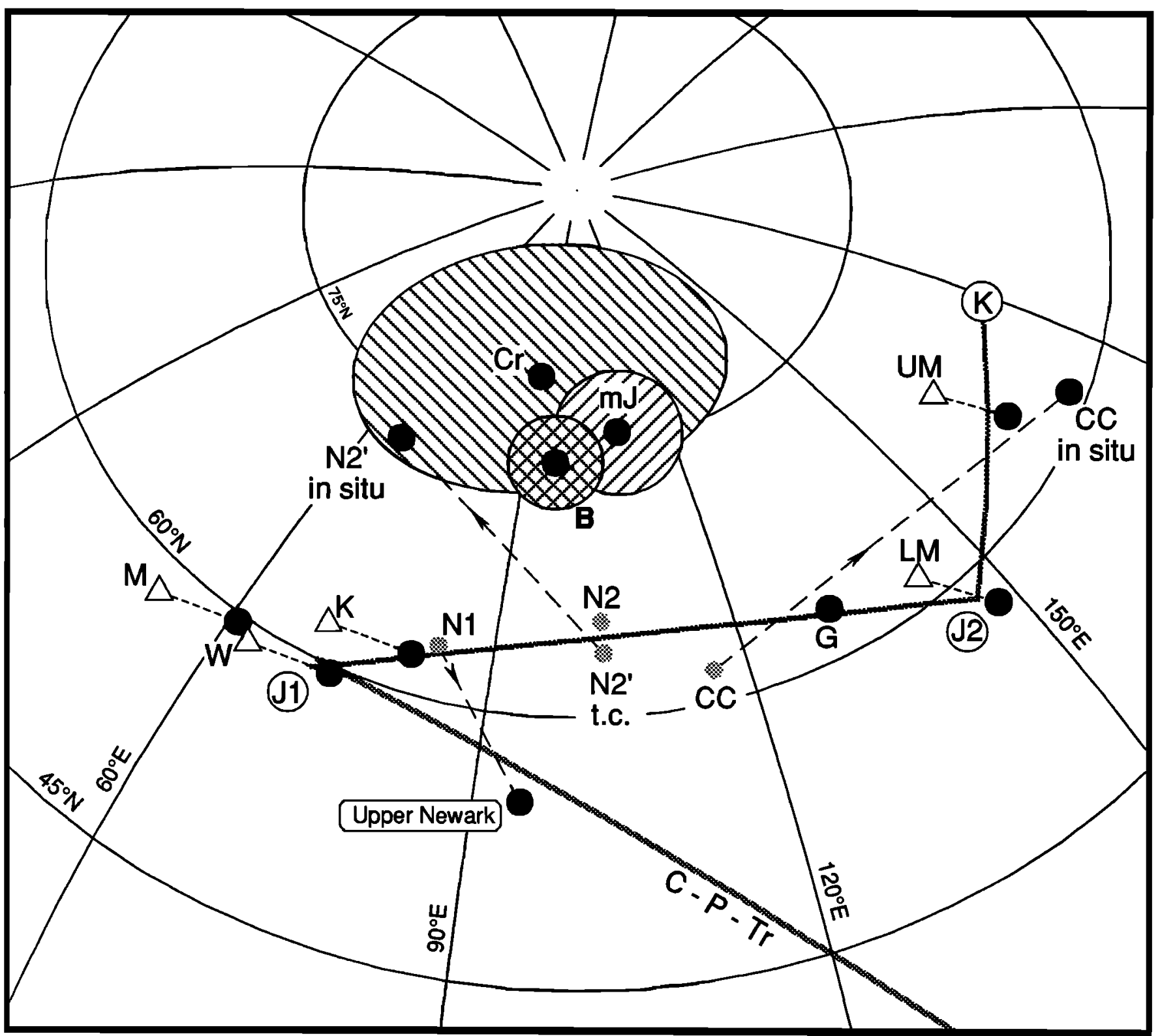

Fig. 9. Jurassic paleomagnetic reference poles for North America and the PEP path (J1-J2, J2-K) of May and Butler [1986] concantenated with the Carboniferous-Permian-Triassic (C-P-TR) track of Gordon et al. [1984]. Jurassic reference poles used in the May and Butler [1986] synthesis include W, Sinemurian Wingate pole [Reeve, 1975]; K, Pliensbachian Kayenta pole [Steiner and Helsley, 1975]; N1 (195 Ma) and N2 (179 Ma), Newark igneous poles [Smith and Noltimier, 1979]; CC, 172 Ma Corral Canyon pole [May et al., 1986]; G, 151 Ma Glance Conglomerate pole [Kluth et al., 1982]; LM (early Tithonian) and UM (late Tithonian), lower and upper Morrison poles [Steiner and Helsley, 1975]. Also shown is M, Sinemurian Moenave pole [Ekstrand and Butler, 1989]. Colorado Plateau poles are indicated by triangles which are connected by short dashed lines to solid circles that indicate the pole positions corrected for $5^{\circ}$ of clockwise Plateau rotation [Bryan and Gordon, 1990]. The grey circles indicate Jurassic reference poles which are the subjects of reinterpretation in the text and include: The N2 pole, an important subset of which are the VGPs reported by Beck [1972] from the intrusions of the Newark and Gettysburg basins which yield a tilt-corrected paleopole (N2' t.c.) similar to N2, but these data are more appropriately considered in geographic coordinates (N2' in situ); the tilt-corrected Corral Canyon pole (CC) that was used in May and Butler's [1986] APW analysis, but the possibility of remagnetization suggests a pole position (CC in situ) in geographic coordinates [Van Fossen and Kent, 1990]; and the N1 pole that is thought to be contaminated by more recent overprints and is superceded by the Hettangian upper Newark pole (Witte and Kent, 1990). Additional Middle Jurassic poles with $\alpha_{95}$ confidence circles which support a high latitude Jurassic APW path for North America are the $175 \mathrm{Ma}$ B component overprint from the Newark basin (B) (this paper), $166 \mathrm{Ma}$ Moat Volcanic pole (Cr) [Van Fossen and Kent, 1990], and, for comparison, the mean Middle Jurassic pole for Gondwana recontructed into North American coordinates (mJ) [Van Fossen and Kent, 1990]. 
the Permo-Carboniferous [Miller and Kent, 1988]. Although the Newark remagnetization developed in a tectonic rift environment whereas the Appalachian remagnetization is clearly related to the Alleghenian orogeny, both the Jurassic and the late Paleozoic remagnetizations were evidently the result of geochemical alteration brought on by regional fluid flow (e.g., [Oliver, 1986]). The Middle Jurassic marks the termination of active rifting and subsidence in the eastern North American rift basins of the continental margin [Olsen et al., 1989; Klitgord et al., 1988; Manspeizer, 1988] and the initiation of seafloor spreading in the North Atlantic [Klitgord and Schouten, 1986]. It was perhaps this transition in tectonic style which generated the episode of hydrothermal activity which was responsible for the resetting of the $\mathrm{K} / \mathrm{Ar}$ isotopic system in the diabase intrusions, the N2 remagnetization of the igneous intrusions, and the $B$ component overprint in the sediments. Further understanding of the mechanism of the pervasive Middle Jurassic remagnetization which we have uncovered in red beds of the Newark basin might have considerable importance to the interpretation of paleomagnetic results from older rocks in the vicinity of the Newark as well as within other rift basins.

\section{IMPLICATIONS FOR APW}

To recapitulate, the Newark red beds contain two significant components of magnetization. The $\mathrm{C}$ component of magnetization was demonstrably acquired at or soon after deposition. The B component was acquired some time after the $\mathrm{C}$ component and after tilting of the strata and is thus properly considered in in situ coordinates with no post acquisition tectonic rotations detectable in the good grouping of site mean directions from throughout the basin.

While the interpretation of the acquisition of the $B$ component magnetization as post tilting depends only on the tilt test described, the evidence that establishes the absolute age of this secondary component is more circumstantial. The B component magnetization is significantly shallower than the Earth's present magnetic field at the sampling locality, indicating that the B component is genuinely ancient and not a recently acquired magnetization. As described above, the Newark red bed B component and the Newark igneous intrusion N2 magnetizations yield similar high-latitude pole positions, and we have suggested that they may be genetically linked to the same Middle Jurassic hydrothermal event which reset the $\mathrm{K}$ Ar system in the intrusions. After the Middle Jurassic the hydrothermal history of the basin was relatively quiescent with apatite and zircon fission track apparent ages from the Newark strata suggesting temperatures less than $\sim 100^{\circ} \mathrm{C}$ after $175 \mathrm{Ma}$ [Roden and Miller, 1989]. The chain of inference which establishes the age of the $B$ component paleopole is admittably indirect, but in the absence of any known postMiddle Jurassic remagnetization mechanism we consider acquisition related to the documented $175 \mathrm{Ma}$ hydrothermal event to be most likely.

Recent analyses of APW for the Mesozoic of North America [Irving and Irving, 1982; Gordon et al., 1984; May and Butler, 1986] have differed in their calculation methods (e.g., running mean or paleomagnetic Euler pole (PEP)). However, as noted by Harrison and Lindh [1982], the choice of reliable paleomagnetic poles which form the basis of each analysis exerts the most powerful control on the resulting APW path. May and Butler [1986] cite seven reference poles regarded as reliable to delineate the J1-J2 PEP track which spans $\sim 50$ m.y. over the Early to Late Jurassic (Figure 9): The Sinemurian Wingate and Pliensbachian Kayenta poles from the Glen Canyon Group [Reeve, 1975; Steiner and Helsley, 1975], the Newark igneous trend N1 (195 Ma) and N2 (179 Ma) poles [Smith and Noltimier, 1979], the $172 \mathrm{Ma}$ Corral Canyon pole [May et al., 1986], the 151 Ma Glance Conglomerate pole [Kluth et al., 1982], and the early Tithonian Lower Morrison pole [Steiner and Helsley, 1975]. The earlier PEP study of Gordon et al. [1984] included the Summerville pole [Steiner, 1978] and the Twin Creek pole [McCabe et al., 1982] which were rejected by May and Butler [1986], but did not include the subsequently published Corral Canyon result.

New paleomagnetic results require further critical evaluation of the Jurassic APW path and the reference pole database it is based upon. The Early Jurassic Moenave pole [Ekstrand and Butler, 1989] confirms earlier results from the Glen Canyon Group and the westward extent of the J1 cusp identified by Gordon et al. [1984] and May and Butler [1986]. On the other hand, recent results from the Newark Supergroup impugn the reliability of the $\mathrm{N} 1$ and $\mathrm{N} 2$ poles. We regard the $\mathrm{N} 1$ pole as superceded by the upper Newark pole from the extrusive zone red beds of Hettangian age and note that the position of the upper Newark pole on the pre-J1 cusp portion of the APW path is consistent with the assigned ages of the upper Newark strata and the Glen Canyon Group [Witte and Kent, 1990]. As discussed earlier in this paper, the $\mathrm{N} 2$ pole is most likely based on a remagnetization acquired late in the deformation history of the basin, hence tilt correction is inappropriate and the resulting $\mathrm{N} 2$ pole position invalid. Likewise, the Corral Canyon pole [May et al., 1986] has been interpreted as a Cretaceous remagnetization acquired after deformation [Van Fossen and Kent, 1990].

The Middle Jurassic B component paleomagnetic pole falls at much higher latitude than the J1-J2 track of the May and Butler [1986] APW path would predict (Figure 9). However, from the preceding discussion, there now remain few reliable reference poles to constrain their model of Jurassic APW for North America between the Early Jurassic Moenave pole and the Late Jurassic Glance Conglomerate pole. On the other hand, our $175 \mathrm{Ma} B$ component pole agrees well with the recently published 166 Ma Moat Volcanic pole from New England [Van Fossen and Kent, 1990]. Moreover, if the Newark and Gettysberg subset [Beck, 1972] of N2 is considered in geographic coordinates, the resulting pole position also falls at a high latitude (Figure 9). Thus the B component magnetization of the Newark basin red beds lends support to the ascent of the North American APW path to high $\left(75^{\circ} \mathrm{N}\right)$ latitudes in the Middle Jurassic, a position that also agrees with the mean Middle Jurassic pole for Gondwana after it is transferred into North American coordinates [Van Fossen and Kent, 1990].

Further paleomagnetic studies of North American Jurassic rocks need to be undertaken to confirm the high-latitude aspect of APW during the Middle Jurassic and to document pole positions that link the high-latitude poles with less controversial segments of the North American APW path.

Acknowledgments. We are grateful for comments on the manuscript from P.E.Olsen. This research was supported in part by the National Science Foundation, Earth Sciences Division (grants EAR87-21142 and EAR88-03814). This is Lamont-Doherty Geological Observatory contribution 4841 . 


\section{REFERENCES}

Beck, M.E., Paleomagnetism of Upper Triassic diabase from southeastern Pennsylvania: Further results, J. Geophys. Res., 77, 5673-5687, 1972.

Bryan, P., and R.G. Gordon, Rotation of the Colorado Plateau: An updated analysis of paleomagnetic poles, Geophys. Res. Lett., 17, 1501-1504, 1990.

Bullard, E. C., J.E. Everett, and A.G. Smith, The fit of the continents around the Atlantic, Proc. R. Soc. London, Ser. A, 258, 41-51, 1965.

Comet, B., The palynostratigraphy and age of the Newark Supergroup, Ph.D. thesis, 505 p., Univ. of Pa., State College, 1977.

Comet, B., and P.E. Olsen, A summary of the biostratigraphy of the Newark Supergroup of eastern North America with comments on early Mesozoic provinciality, in III Congresso Latinoamericano de Paleontologia, Mexico, Simposio Sobre Floras del Triasico Tardio, su Fitogeografia y Paleoecologia, Memoria, edited by R. Weber, pp. 67-81, Instituto de Geologia Universidad Nacional Autonoma de Mexico, Mexico City, 1985.

deBoer, J.Z., J.G. McHone, J.H. Puffer, P.C. Ragland, and D. Whittington, Mesozoic and Cenozoic magmatism, in The Geology of North America, vol. I-2, The Atlantic Contiental Margin, U.S., edited by R.E. Sheridan and J.A. Grow, Geological Society of America, Pp. 217-241, Boulder, Colo., 1988.

Dodson, M.H. and E. McClelland-Brown, Magnetic blocking temperatures of single-domain grains during slow cooling, $J$. Geophys. Res., 85, 2625-2637, 1980.

Dunning, G.R. and J.P. Hodych, U/Pb zircon and baddeleyite ages for the Palisades and Gettysburg sills of the northeastem United States: Implications for the age of the Triassic/Jurassic boundary, Geology, is, 795-798, 1990.

Ekstrand, E.J., and R.F. Butler, Paleomagnetism of the Moenave Formation: Implications for the Mesozoic North American apparent polar wander path, Geology, 17, 245-248, 1989.

Fisher, R.A., Dispersion on a sphere, Proc. R. Soc. London, Ser. A, 217, 295-305, 1953

Gordon, R.G., A. Cox, and S. O'Hare, Paleomagnetic Euler poles and the apparent polar wander and absolute motion of North America since the Carboniferous, Tectonics, 3, 499-537, 1984.

Harrison, C.G.A., and T. Lindh, A polar wandering curve for North America during the Mesozoic and Cenozoic, J. Geophys. Res., 87, 1903-1920, 1982.

Irving, E., and G.A. Irving, Apparent polar wander paths Carboniferous through Cenozoic and the assembly of Gondwana, Geophys. Surv., 5, $141-188,1982$

Irving, E., and N.D. Opdyke, The paleomagnetism of the Bloomsburg Red beds and its possible application to the tectonic history of the Appalachians, Geophys. J. R. Astron. Soc., 9, 153-167, 1965.

Kent, D.V., and J.D. Miller, Red beds and thermoviscous magnetization theory, Geophys. Res. Lett., 14, 327-330, 1987.

Kirschvink, J.L., The least-squares line and plane and the analysis of paleomagnetic data, Geophys. J. R. Astron. Soc., 62, 699-718, 1980.

Klitgord, K.D., and H. Schouten, Plate kinematics of the central Atlantic, in The Geology of North America, vol. M, The Western North Atlantic Region, edited by P.R. Vogt and B.E. Tucholke, Pp. 351-378, Geological Society of America, Boulder, Colo., 1986.

Klitgord, K.D., D.R. Hutchinson, and H. Schouten, U.S. Atlantic continental margin: Structural and tectonic framework, in The Geology of North America, vol. I-2, The Atlantic Continental Margin, U.S., edited by R.E. Sheridan and J.A. Grow, pp. 19-55, Geological Society of America, Boulder, Colo., 1988.

Kluth, C.F., R.F. Butler, L.E. Harding, M. Shafiqullah, and P.E. Damon, Paleomagnetism of Late Jurassic rocks in the northern Canelo Hills, southeastem Arizona, J. Geophys. Res., 87, 70797086, 1982.

Kodama, K.P., Magnetic and gravity evidence for a subsurface connection between the Palisades sill and the Ladentown Basalts, Geol. Soc. Am. Bull., 94, 151-158, 1983.

Lyttle, P.T., and J.B. Epstein, Geologic map of the Newark $1^{\circ} \times 2^{\circ}$ quadrangle, New Jersey, Pennsylvania, and New York, U.S. Geol. Surv. Misc. Invest. Ser. Map, I-1715, 1987.

Manspeizer, W., Triassic-Jurassic rifting and opening of the Atlantic: An overview, in Triassic-Jurassic Rifting, Continental Breakup and the Origin of the Atlantic Ocean and Passive Margins, edited by W. Manspeizer, pp. 41-79, Elsevier, New York, 1988.
May, S.R., and R.F. Butler, North American Jurassic apparent polar wander: Implications for plate motion, paleogeography, and Cordilleran tectonics, J. Geophys. Res., 91, 11519-11544, 1986.

May, S.R., R.F. Butler, M. Shafiqullah, and P.E. Damon, Paleomagnetism of Jurassic rocks in the Patagonia Mountains, southeastem Arizona: Implications for the North American $170 \mathrm{Ma}$ reference pole, J. Geophys. Res., 91, 11545-11555, 1986.

McCabe, C., R. Van der Voo, and B.H. Wilkinson, Paleomagnetic and rock magnetic results from the Twin Creek Formation (Middle Jurassic) Wyoming, Earth Planet. Sci. Lett., 60, 140-146, 1982.

McFadden, P.L., and F.J. Lowes, The discrimination of mean directions drawn from Fisher distributions, Geophys. J. R. Astron. Soc., 67, 19-33, 1981.

McFadden, P.L., and M.W. McElhinny, Classification of the reversal test in paleomagnetism, Geophys. J. Int., 103, 725-729, 1990.

McIntosh, W.C., R.B. Hargraves, and C.L. West, Paleomagnetism and oxide mineralogy of Upper Triassic to Lower Jurassic red beds and basalts in the Newark basin, Geal. Soc. Am. Bull., 96, 463-480, 1985.

Miller, J.D., and D.V. Kent, Regional trends in the timing of Alleghanian remagnetization in the Appalachians, Geology, 16, 588-591, 1988.

Ogg, J.G. and M.B. Steiner, Jurassic magnetic polarity time scale: Current status and compilation, in International Symposium on Jurassic Stratigraphy, symp. vol. III, edited by O. Michelsen and A. Zeiss, Pp. 777-794, Geological Survey of Denmark, Copenhagan, 1984.

Oliver, J., Fluids expelled tectonically from orogenic belts: Their role in hydrocarbon migration and other geological phenomena, Geology, 14, 99-102, 1986.

Olsen, P.E., and M. Fedosh, Duration of the early Mesozoic extrusive igneous episode in eastem North America determined by use of Milankovitch-type cycles, Geol. Soc. of Am. Abstracts with Programs, 20, pp. 59, 1988.

Olsen, P.E., R.W. Schlische, and P.J.W. Gore, Tectonic, Depositional, and Paleoecological History of the Early Mesozoic Rift Basins, Eastem North America, Field Trip Guide, vol. T351, 174 pp., AGU, Washington, D. C., 1989.

Pullaiah, G., E., Irving, K.L. Buchan, and D.J. Dunlop, Magnetization changes caused by burial and uplift, Earth Planet. Sci. Lett., 28, 122 $143,1975$.

Ratcliffe, N.M., Reinterpretation of the relationship of the westem extension of the Palisades sill to the lava flows at Ladentown, New York, based on new core data, in Studies of the Early Mesozoic Basins of the Eastem United States, edited by A.J. Froelich and G.R Robinson, Jr., U.S. Geol. Surv. Bull., 1776, 194-200, 1988.

Ratcliffe, N.M., and W.C. Burton, Fault reactivation models for origin of the Newark basin and studies related to eastem U.S. seismicity, in Proceedings of the Second U.S. Geological Survey Workshop on the Early Mesozoic Basins of the Eastern United States, edited by G.R. Robinson, Jr., and A.J. Froelich, U.S. Geol. Surv. Circ. 946, 113135, 1985.

Reeve, S.C., Paleomagnetic studies of sedimentary rocks of Cambrian and Triassic age, Ph.D. thesis, 426 pp., Univ. of Tex. at Dallas, Richardson, 1975.

Roden, M.K., and D.S. Miller, Thermal history of Hartford, Newark, and Taylorsville basins using fission-track analysis, Geol. Soc. of Am. Abstracts with Programs, 21, A266, 1989.

Smith, T.E., and H.C. Noltimier, Paleomagnetism of the Newark trend igneous rocks of the north central Appalachians and the opening of the central Atlantic Ocean, Am. J. Sci., 279, 778-807, 1979.

Stamatakos, J., and K.P. Kodama, Strained remanence in the Mauch Chunk Formation (abstract), Eos Trans. AGU, 71, 492, 1990.

Steiner, M.B., Magnetic polarity during the Middle Jurassic as recorded in the Summerville and Curtis Formations, Earth Planet. Sci. Lett., $38,331-345,1978$.

Steiner, M.B., and C.E. Helsley, Reversal pattem and apparent polar wander for the Late Jurassic, Geol. Soc. Am. Bull., 36, 1537-1543, 1975.

Sutter, J.F., Innovative approaches to the dating of igneous events in the early Mesozoic basins of the eastern United States, in Studies of the Early Mesozoic Basins of the Eastem United States, edited by A.J. Froelich and G.R. Robinson, Jr., U.S. Geol. Surv. Bull., 1776, 194-200, 1988.

Sutter, J.F. and T.E. Smith, ${ }^{40} \mathrm{Ar} /{ }^{39} \mathrm{Ar}$ ages of diabase intrusions from 
Newark trend basins in Connecticut and Maryland, Initiation of central Atlantic rifting, Am. J. Sci., 279, 801-831, 1979.

Swanson, M.T., Preexisting fault control for Mesozoic basin formation in eastem North America, Geology, 14, 419-422, 1986.

Van Fossen, M.C., and D.V. Kent, High-latitude paleomagnetic poles from Jurassic plutons and moat volcanics in New England and the controversey regarding Jurassic apparent polar wander for North America, J. Geophys. Res., 95, 17503-17516, 1990.

White, N.J., J.A. Jackson, and D.P. McKenzie, The relationship between the geometry of normal faults and that of the sedimentary layers in their hanging walls, J. Struct. Geol., 8, 897-909, 1986.

Witte, W.K., and D.V. Kent, A middle Carnian to early Norian ( 225

$\mathrm{Ma}$ ) paleopole from sediments of the Newark basin, Pennsylvania, Geol. Soc. Am. Bull., 101, 1118-1126, 1989.

Witte, W.K., and D.V. Kent, 1990, The paleomagnetism of red beds and basalts of the Hettangian extrusive zone, Newark Basin, New Jersey, J. Geophys. Res., 95, 17533-17545.

Witte, W.K., D.V. Kent, and P.E. Olsen, Magnetostratigraphy and paleomagnetic poles from the Late Triassic-earliest Jurassic strata of the Newark basin, Geol. Soc. Am. Bull., in press, 1991.

Zijderveld, J.D.A., A.C. demagnetization of rocks: Analysis of results, in Methods in Paleomagnetism, edited by D.W. Collinson, M.K. Creer, and S.K. Runcom, pp. 254-286, Elsevier, New York, 1967.

D. V. Kent and W. K. Witte, Lamont-Doherty Geological Observatory, Palisades, NY 10964, USA.

(Received January 22, 1991;

revised June 27, 1991;

accepted July 10, 1991.) 